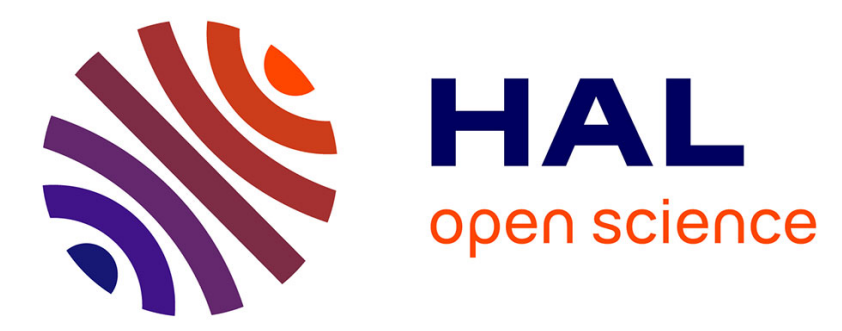

\title{
Redescription of the cranial skeleton of the Early Devonian (Emsian) sarcopterygian Durialepis edentatus Otto (Dipnomorpha, Porolepiformes)
}

\author{
Jorge Mondéjar-fernández, Matt Friedman, Sam Giles
}

\section{- To cite this version:}

Jorge Mondéjar-fernández, Matt Friedman, Sam Giles. Redescription of the cranial skeleton of the Early Devonian (Emsian) sarcopterygian Durialepis edentatus Otto (Dipnomorpha, Porolepiformes). Special papers in palaeontology, 2020, 10.1002/spp2.1315 . mnhn-02976944

\section{HAL Id: mnhn-02976944}

\section{https://hal-mnhn.archives-ouvertes.fr/mnhn-02976944}

Submitted on 10 Nov 2020

HAL is a multi-disciplinary open access archive for the deposit and dissemination of scientific research documents, whether they are published or not. The documents may come from teaching and research institutions in France or abroad, or from public or private research centers.
L'archive ouverte pluridisciplinaire HAL, est destinée au dépôt et à la diffusion de documents scientifiques de niveau recherche, publiés ou non, émanant des établissements d'enseignement et de recherche français ou étrangers, des laboratoires publics ou privés. 
Redescription of the cranial skeleton of the Early Devonian (Emsian) sarcopterygian Durialepis edentatus Otto, 2007 (Dipnomorpha; Porolepiformes)

by JORGE MONDÉJAR-FERNÁNDEZ ${ }^{1}$, MATT FRIEDMAN ${ }^{2}$ and SAM GILES $^{3,4 *}$

${ }^{1}$ Institut de Systématique, Evolution, Biodiversité (ISYEB),

Muséum National d'Histoire Naturelle, Sorbonne Université, CNRS, EPHE ; CP 30, 25 rue

Cuvier, 75005 Paris, France; e-mail: jorge.mondejar-fernandez@mnhn.fr

${ }^{2}$ Museum of Paleontology and Department of Earth and Environmental Sciences, University of Michigan, 1105 N University Ave, Ann Arbor, MI, 48109-1079, USA; email:

mfriedm@umich.edu

${ }^{3}$ School of Geography Earth and Environmental Sciences, University of Birmingham, Birmingham, UK, B15 2TT; email: s.giles.1@bham.ac.uk

${ }^{4}$ Christ Church, Oxford, UK, OX1 1DP

* Corresponding authors 


\section{ABSTRACT}

Porolepiforms represent a clade of Devonian stem lungfishes, divided into the cosminebearing and likely paraphyletic 'Porolepidae' (e.g., Porolepis, Heimenia) and the cosminefree and stratigraphically younger Holoptychiidae (e.g., Holoptychius, Glyptolepis, Laccognathus). Data on the dermoskeleton are available for both groups, but are more limited for 'porolepids'. Here we present new information on the 'porolepid' Durialepis edentatus from the Emsian (Early Devonian) of Germany based on micro-CT scanning. The material comprises an articulated skull of a single three-dimensionally preserved individual. The arrangement of the cheekbones of Durialepis edentatus recalls that of Porolepis brevis, with the occurrence of two subsidiary squamosals. However, the parieto-ethmoidal and postparietal shields are roughly equal in size, a condition similar to that of Glyptolepis groenlandica and intermediate between Porolepis brevis and holoptychiids. A large parasymphysial tooth plate displays five tooth rows with three large tusks in the median row, another intermediate arrangement between the primitive condition of Porolepis sp. (eight rows) and holoptychiids (five or fewer rows). Remarkably among porolepiforms, this dental plate is perfectly symmetrical. Despite the occurrence of cosmine and rhombic scales, the combination of traits displayed in Durialepis deviates from Porolepis in several ways, reflecting features shared with holoptychiids to the exclusion of other 'porolepids'. Durialepis edentatus is thus a key addition to our knowledge of 'porolepid' anatomy. Because Durialepis edentatus preserves much of the cranial and postcranial skeleton in a single individual, it represents a suitable early dipnomorph representative for inclusion in phylogenetic analyses on sarcopterygians and early osteichthyans.

Key words: computed tomography, cranial skeleton, Devonian, Sarcopterygii, stem-lungfish 


\section{INTRODUCTION}

Porolepiformes is a moderately diverse clade of stem lungfishes, commonly associated with fully continental or marginal marine depositional environments from the Early to the Late Devonian (Lochkovian-Famennian). They are characterized by the presence of dendrodont-type teeth, sub-squamosal bones, absence of differentiated intertemporal and supratemporal bones, contribution of the nasal series to the skull roof margin posterior to the orbit, and by the otico-occipital lateral line canal passing through the radiation centre of the postparietal bones (Schultze 1969; Panchen \& Smithson 1987; Ahlberg 1989, 1991; Janvier 1996).

Comprising roughly a dozen genera, porolepiforms have traditionally been divided into the cosmine-bearing, stratigraphically older-and likely paraphyletic (Jarvik 1980; Maisey 1986; Ahlberg 1991, 1992a,b; Clément 2001a,b)—'Porolepidae' (e.g., Porolepis, Heimenia, Durialepis) and the cosmine-free and stratigraphically younger Holoptychiidae (e.g., Glyptolepis, Laccognathus, Holoptychius). A new family, Ventalepididae, has recently been created to include the enigmatic Ventalepis ketleriensis (Schultze 1980) on the basis of a unique combination of scale structure and dermal bone ornamentation (Lebedev \& Lukševičs 2018).

Data for holoptychiids dominates current understanding of porolepiform anatomy, with more restricted information available for the older and morphologically primitive 'porolepids'. With the exception of Porolepis from the Pragian-Emsian of Europe (P. hefteri, P. kureikensis, P. posnaniensis, P. rhenana, P. siegenensis, P. taymirica, P. uralensis), Spitsbergen (P. brevis, P. elongata, P. spitbergensis) and Australia (P. foxi) (Jarvik 1942, 1972; Clément 2004; Johanson et al. 2013), the best known porolepiforms are holoptychiids: 
Glyptolepis from the Eifelian-Frasnian of Greenland (G. groendlandica) and Europe ( $G$. baltica, G. bendeni, G. elegans, G. leptopterus, G. microlepidotus, G. orbis, G. paucidens, G. quadrata, G. radians, G. remota) (Thomson 1966; Andrews \& Westoll 1970; Jarvik 1972), Laccognathus from the Givetian-Frasnian of Europe (L. panderi, L. grossi) and North America (L. embryi) (Gross 1941; Vorobyeva 1980, 2006; Downs et al. 2011), Holoptychius from the Frasnian-Famennian of Europe (H. flemingi, H. giganteus, $H$. halli, H. ishora, $H$. nobilissimus, H. radiatus, $H$. scheii, H. taylori, H. tuberculatus), North (H. bergmanni, $H$. jarviki) and South America and Asia (Holoptychius sp.) (Andrews \& Westoll 1970; Cloutier \& Schultze 1996; Miller \& Brazeau 2007; Downs et al. 2013; Mondéjar-Fernández \& Janvier 2014), Quebecius quebecensis from the Frasnian of Québec (Schultze \& Arsenault 1987; Cloutier \& Schultze 1996), and Nasogaluakus chorni from the Emsian of Canada (Schultze 2000). Other porolepiforms are known from less complete or disarticulated material. The 'porolepid' Heimenia ensis from the Emsian-Eifelian of Spitsbergen, Europe, North America, and South-East Asia (Clément 2001a,b; Mondéjar-Fernández \& Clément 2012) is represented by a partial articulated postcranium and referred cranial remains. Duffichthys mirabilis, from the Frasnian of Scotland (Ahlberg 1992a), is known only from a partial jaw, but is included among holoptychiids on the basis of distinctive dental and mandibular characteristics. Other taxa attributed to Porolepiformes such as Hamodus luktevitshi (Obruchev 1933), Paraglyptolepis karkiensis (Vorobyeva 1987) and Pseudosauripterus anglicus (Ball et al. 1961) from the Middle-Late Devonian of the Baltic States, Russia and the British Isles are known mostly from disarticulated dental or scale material, and their validity is questionable.

The classic suite of 'porolepid' remains from Spitsbergen and Poland is joined by additional material from roughly coeval deposits in the Eifel region of Germany. Most of these remains comprise isolated scales and bones tentatively attributed to Porolepis (Gross 1933, 1936, 1941, 1956). However, Jessen (1989) reported a single specimen of a large 
articulated individual. He acknowledged similarities with Heimenia ensis (Ørvig 1969), for example scale ornamentation, but used the distribution of postparietal pit lines to diagnose the specimen as a species of Porolepis similar to P. elongata from Spitsbergen. Otto (2007) redescribed the articulated Eifel porolepiform following additional mechanical preparation that revealed details of the internal skeleton, including the neurocranium. He erected a new species and genus to accommodate this specimen: Durialepis edentatus. Otto (2007) justified this interpretation by noting differences between the ethmosphenoid of Durialepis and those attributed to Porolepis (e.g., P. brevis), as well as the apparent reduction of the size of the dentition and lack of large teeth on the parasphenoid (hence its specific name, edentatus).

Jessen (1989) and Otto (2007) described visible portions of the external skeleton of Durialepis edentatus, with Otto (2007) adding description of external features of the endocranium. However, many aspects of the skull remained obscured by matrix, concealing potentially important anatomical features. Here we use high-resolution micro-computed Xray tomography $(\mu \mathrm{CT})$ (Fig. 1) to examine anatomical structures not visible to previous researchers, and to test past interpretations based only on external examination. We place emphasis on the dermal skeleton, palate and hyoid arch. More broadly, we look to establish Durialepis edentatus as an anatomically coherent 'porolepid'-grade taxon for inclusion in phylogenetic analyses, and hope that it motivates much-needed revision of other 'porolepid' material.

\section{MATERIALS AND METHODS}

\section{Material}

Durialepis edentatus, GIK 991, Geologisches Institut Köln, Cologne, Germany. Holotype specimen preserving a near-complete and articulated individual across several blocks. 


\title{
Methods
}

The anteriormost block of GIK 991, which preserves the skull, cheek and operculogular series was scanned using a Nikon Metrology HMX ST 225 CT scanner at the Natural History Museum, London, with the following settings: $205 \mathrm{kV} ; 160 \mu \mathrm{a} ; 6284$ projections; $0.5 \mathrm{~mm}$ copper filter; with a resulting voxel size of $85.7 \mu \mathrm{m}$. Additional scans were conducted with the same settings with the region of interest focussed on the parieto-ethmoidal shield (voxel sixe: $30.5 \mu \mathrm{m}$ ) and the block containing the postparietal shield (voxel size: $34.2 \mu \mathrm{m}$ ). Data were segmented manually in Mimics Innovation Suite V.18.0 (http://biomedical.materialise.com/mimics; Materialise, Leuven, Belgium) and resultant PLY files exported into and rendered in Blender V.2.77a (http://www.blender.org; Blender Institute, Amsterdam, Netherlands).

\section{SYSTEMATIC PALEONTOLOGY}

\author{
Class OSTEICHTHYES Huxley, 1880 \\ Subclass SARCOPTERYGII Romer, 1955 \\ Order DIPNOMORPHA Ahlberg, 1991 \\ Suborder POROLEPIFORMES Berg, 1937
}

Durialepis edentatus Otto, 2007

Figs. $1-9$

Porolepis cf. elongata (Jarvik, 1942) Jessen, 1989, p. 17-24.

Durialepis edentatus Otto, 2007, p. 6-25, Abb. 1-9. 


\section{Holotype}

GIK 991, partially disarticulated remains from a single three-dimensionally preserved individual across several blocks preserving different regions of the skeleton: skull with cheek, parieto-ethmoidal shield, operculogular system, shoulder girdle; postparietal shield, extrascapular bones; upper opercular series and extrascapular bone; fragment of the pectoral girdle and associated squamation; isolated squamosal; portions of the squamation; lepidotrichia and bases of median fins (Jessen 1989; pl.1-3; Otto 2007; fig.1-9).

\section{Locality}

Schleiden (Eifel Hills), North Rhine-Westphalia, Germany.

\section{Formation and age}

Klerf Formation, Early Devonian (early Emsian). Age assessments of the Rhenish Early Devonian are based principally on brachiopods (Jansen 2016) An early Emsian age for the Klerf Formation is corroborated by the presence of the pteraspid Rhinopteraspis dunensis (Otto 2007), which ranges from late Pragian to early Emsian (Blieck \& Elliott 2017). Jansen (2016) interpreted the Klerf Formation as representing a marginal marine setting, transitional between fully terrestrial, freshwater and more offshore facies represented in the Rhenish Massif.

\section{Diagnosis}

Modified from Otto (2007): porolepiform distinguished by the following unique combination of characters: parieto-ethmoidal and postparietal shields similar in length; small and narrow parasphenoid; reduced parasphenoid dentition consisting of a single row of small teeth within 
a midline gutter; buccohypophysial canal located roughly at midlength of the ethmoid division of the braincase; five rows of teeth on parasymphysial tooth whorl in total, symmetrically arranged about a central midline row; extensive development of cosmine on dermal bones.

\section{Remarks on 'porolepid' taxonomy}

'Porolepid' taxonomy is in need of revision. The type species of both Porolepis and Heimenia were erected on the basis of isolated scales: Heimenia ensis from the late Emsian of Spitsbergen (Ørvig 1969) and Porolepis posnaniensis from erratic boulders in Silesia (Kade 1858). Additional material has since been attributed to both genera. The suite of remains now assigned to Heimenia includes an isolated jaw (Jarvik 1972), an associated mandible, palate, and braincase (Clément 2001a,b), and an articulated postcranium (Mondéjar-Fernández \& Clément 2012); all are assumed to belong to $H$. ensis. Kulczycki (1960) attributed to P. posnaniensis a large lower jaw fragment from the Early Devonian of the Holy Cross Mountains in Poland, although it is also possible that it belongs to Heimenia (Clément 2001b).

The history of remains attributed to Porolepis is more complex. Gross (1933) erected two species of Porolepis based on isolated cleithra from the Early Devonian of Germany: Porolepis siegenensis (Gross 1933: pl. 8, figs 1-2) from the upper Sigenian of Overath and Porolepis hefteri (Gross 1933: pl. 8, fig. 3) from the "Unterkoblenzschichten" near Koblenz. Jarvik (1942) divided the Porolepis material from the Early Devonian of Spitsbergen into three species based on differing proportions of the ethmosphenoid ( $P$. spitsbergensis, $P$. brevis, . elongata). To this list of European material, Johanson et al. (2013) added P. foxi on the basis of mandibular material from the Early Devonian of Australia. However, when dealing with the Spitsbergen material of Porolepis, Clément (2001b) argued that P. elongata 
is a junior synonym of $P$. brevis, representing a different ontogenetic stage. Moreover, supposedly diagnostic features of $P$. spitsbergensis are the result of post mortem deformation. Clément (2001b) informally suggested that P. brevis is the only taxon known from undistorted remains and should be the senior synonym for all Porolepis species from Spitsbergen. However, P. spitsbergensis is the first species to be cited in Jarvik (1942) and thus, according to the rules of zoological nomenclature, should be considered the senior synonym.

The holotype of Durialepis edentatus is by far the most informative porolepiform specimen described from the Early Devonian of southwestern Germany. Gross (1933) reported the first remains of porolepiforms from these strata but attributed them to Porolepis (P. siegenensis and P. hefteri). Otto (2007) suggested the presence of two additional Early Devonian German porolepiform taxa, both represented by unpublished material. The first of these derives from multiple localities in the Rhenish Mountains, and according to Otto (2007) differs from Durialepis edentatus in proportions of the ethmoid division of the braincase and the presence of well-developed palatal dentition (but see new account of dentition below). The second unnamed porolepiform is known from a single specimen from Waxweiler and housed in a private collection. It is distinguished by peculiar cranial morphology and the absence of cosmine. We follow Otto's recognition of Durialepis edentatus as distinct from these other forms, but acknowledge that the taxonomic status of this and other 'porolepids' is likely to change with further investigation of the group.

\section{DESCRIPTION}

The dermal bones of the skull were described and figured by Jessen (1989) and Otto (2007). Jessen's preliminary description was limited to exposed regions of the holotype (GIK 991), 
with Otto providing further details of the cheek and mandible following additional preparation. Here we use CT scanning and external examination to provide a detailed description of the dermal bones and the internal mandibular and hyoid skeletons. Otto's (2007) descriptions are briefly summarised and supplemented where relevant.

\section{Dermal skull roof}

Ethmoid division. The ethmoid division (Figs 1-2) is in near-articulation with the remainder of the skull and covered by a thick layer of cosmine that obscures most sutures (Jessen 1989; Otto 2007). Only a small portion of the median suture between the parietals can be seen (su.Pa, Fig. 2B). The pineal foramen (pi.fo, Fig. 2B) is open and a straight pit line (pl.Pa. Fig. 2B) extends parallel to the overlap facet for the postorbital. Large pores, interspersed with the much smaller openings of the cosmine pore canal network, indicate the presence of an intricate web of canals (Figs 2-3) associated with the lateral line. The radiating pattern of these branches seems to match separate ossifications centres. Two large parietals appear to lie posterior to the pineal opening, evidenced by radiation of the canals (gc.Pa. Fig. 3B). The disorganized canal arrangement anterior to the parietals suggests many small ossification centres (e.g. nasal series and postrostral mosaic).

The lateral line network of the parieto-ethmoidal shield (Fig. 3) comprises paired main canals from which the ramifying canal network described above radiates. The supraorbital canals (soc, Figs 2B, 3A) are lyre-shaped in dorsal view. It is unclear whether the ethmoid commissure (Eth.co, Fig. 3B) and infraorbital canal (ioc, Fig. 3B) are borne along the premaxillary suture or fully within the premaxilla. The infraorbital canal extends below both the anterior and posterior nostrils. 
Otoccipital division. The otoccipital division is detached from the remainder of the specimen, and the prespiracular, extratemporal and lateral extrascapular are displaced above the remainder of the postparietal shield (Figs 1-3). Despite the cosmine covering of the skull roof, certain sutures are visible (Figs 1-2), with patterns of sensory canal radiation centres corroborating the positions of ossifications (Fig. 3E, F). Large pores piercing the cosmine sheet indicate the course of the otico-occipital lateral line canal.

The postparietals are the longest bones of the skull roof (Pp, Figs 1-3). The lateral margin is gently concave to the level of the tabular, and forms an overlapping area for the prespiracular (contra the postorbital of Otto 2007, fig. 5E; ov.Prsp, Fig. 2D). The suture with the tabular forms a sinusoid embayment, and the posterior margin is very slightly concave. Two short pit lines are present in the middle of the right postparietal at the level of the anterior edge of the tabulars, straddling the oblique crack across the left postparietal (Jessen 1989, pl. 1; pl.Pp, Fig. 2D).

Both left and right tabulars are tightly sutured to the postparietals (Ta, Fig. 2D). They are narrow, with a curved medial margin. A straight lateral margin indicates the original position of the extratemporal, which is displaced dorsally. A faint pit line is visible on the right tabular (pl.Ta, Fig. 4B).

The left extratemporal (Ext, Figs 1-2) is displaced dorsally. It is small, triangular, and anteriorly tapering, and a slightly sigmoid ventral margin frames the dorsal margin of the spiracular opening. Large pores indicate substantial ramification of the otico-occipital lateral line canal into the extratemporal (see below).

The left lateral extrascapular (L.Ex, Figs 1-2) is broken between two blocks. It is broad, with a scalloped anterior edge, and bears a short pit line (pl.L.Ex, Fig. 1C). The medial margin is broken, although a short portion of the overlap area for a median extrascapular, and 
a narrow sliver of the median extrascapular itself, are preserved on more posterior blocks (Otto 2007).

The anterior portion of the lateral line canal (poc, Fig. 3D) extends in a straight line before turning sharply into the tabular at the level of the postparietal ossification centre. Within the tabular, the sensory canal displays a triangular expansion before narrowing again (ex.poc.Ta, Fig. 3D). Posterior to the expansion, a lateral branch turns into the extratemporal (poc.Ext, Fig. 2B). The sensory canal continues posteriorly into the lateral extrascapular where the supratemporal commissure (scc, Fig. 2B) branches medially towards the median extrascapular.

Canal system. A further canal network lies ventral to the lateral line system (Fig. 3), within the braincase, but is associated with the overlying dermal sensory network. A narrow transverse canal (tr.c, Fig. 3A) lies just posterior to the point at which the two supraorbital canals diverge, and a complex network of canals, representing ophthalmic branches of the facial nerve, fill the region of the snout anteromedially. These canals anastomose with one another and the transverse canal, and the distal tips of their smallest branches are associated with the sensory canals of the dermal skull roof. On each side of the skull, these networks converge to a main trunk, which opens onto the orbital roof in the anterior half of the orbit (opn, Fig. 3A).

Cheek

The left cheekplate is slightly crushed but complete and articulated (Figs 1, 4). It consists of a maxilla, lacrimal, postorbital, prespiracular, jugal, principal squamosal, subsidiary squamosals, preopercular, quadratojugal, and preoperculosubmandibular (Otto 2007). The 
occurrence of large pores perforating the cosmine layer indicate the course of the lateral canal system.

The maxilla is fractured and incompletely preserved (Mx, Figs 4B, 5). It is narrow and rectangular, with a rounded anterior tip, and bears a single row of small teeth that do not reach the jaw hinge. In lingual view, it displays a long horizontal groove for articulation with the dermopalatine and ectopterygoid. Large pores indicate the presence of ramifying sensory canals projecting from the infraorbital lateral line canal.

The lacrimal is rectangular and straddles the ventral margin of the orbit (La, Fig. 4B). Its ventral margin abuts a broad overlap area on the maxilla, and its posteroventral margin tapers to contact the jugal. The posterior nostril fits in a notch in the antero-dorsal corner of the bone (p.no, Fig. 1C).

The postorbital is large and frames the orbit dorsally (Po, Fig. 4B). The postorbital lateral line canal passes into the parieto-ethmoidal shield as evidenced by the occurrence of large pores in the postorbital.

The prespiracular is large, with a rounded posterior margin (Prsp, Figs 1C, 4B). It is split between two blocks, overlapping the squamosal ventrally and articulating with the postparietal and tabular dorsally. A short contact with the extratemporal might have also occurred along the posterior-most edge.

The postero-ventral margin of the orbit is partially framed by the jugal (Ju, Fig. 4B). Large pores and grooves confirm that the jugal contains the junction between the postorbital and infraorbital lateral lines.

Posterior to the jugal is a characteristic ensemble of squamosals: the principal squamosal (bearing the preopercular lateral line canal) and two subsidiary squamosals (anterior and posterior; Figs 1, 4B). The principal squamosal is pierced by the preopercular lateral line through its lower half. Pit lines are not apparent on either the left or right 
squamosal (Otto 2007, fig. 6B,C). The two subsidiary squamosals are of similar size and roughly triangular in shape, with both tapering edges pointing posteriorly. Lateral line pores and pit lines are absent from both, although the anterior one shows a reduced pore cluster.

The narrow preopercular (Pop, Fig. 4B) is roughly rhomboidal in shape. The posterior margin is slightly jagged and has a curved contact with the opercular and subopercular.

The quadratojugal (Qj, Fig. 4B) is ovoid and elongate, separating the preopercular from the maxilla. A putative pit line (?pl.Qj, Fig. 4B) might have been present but is difficult to confirm due to damage.

The preoperculosubmandibular is small and hexagonal (Psbm, Fig. 4B). The preopercular canal passes through the vertical midline of the bone to join the submandibular canal.

Palate

The palate is complete on the left side of the specimen, and comprises the vomer, palatoquadrate, dermopalatine, ectopterygoid and entopterygoid (Figs 1, 4-5). Previous accounts by Otto (2007) can now be complemented.

The vomer (Vo, Figs 1F, 4D) is roughly rectangular in shape and carries two large fangs, with large enamel striae (Vo.f, Fig. 4D). Anterior to the fangs, a single row of small denticles (Vo.t, Fig. 4D) sits on the anterior vertical lamina (v.Vo, Fig. 4D). A pointed anteromedial process (h.Vo, Fig. 4D) covers the lateral wall of the left internasal cavity (Otto 2007: fig. 4D). A dorsolateral process is also present. The extension of the overlapping facets for the vomers in the anterior portion of the ethmoid suggests that the vomers diverged anteriorly and did not contact the parasphenoid posteriorly. 
The palatoquadrate (Pq, Fig. 5) is almost entirely preserved. The dorsal-most region is pierced by a series of small foramina, probably transmitting fine canals between the palatoquadrate and the entopterygoid. The apical process of the pars autopalatina (pa.au, Fig. 5B) is situated at the level of the anterior tip of the dermopalatine. The processus ascendens (pr.as, Fig. 5D) is located dorsal to the dermopalatine, and is embayed on it its anterior margin. Posterior to the processus ascendens, the dorsal margin of the palatoquadrate (d.m, Fig. 5B) is incomplete. A spiraculo-hyomandibular recess (re.sh, Fig. 5D) is present along the postero-dorsal margin, bounded ventrally by the entopterygoid. The pars quadrata (pa.qd, Fig. 5D) articulates with the Meckelian ossification of the lower jaw through two cotyles.

The dermopalatine and ectopterygoid (Dp, Ectp, Fig. 5B) are preserved in articulation, the ectopterygoid being the larger of the two. Each bone bears a single fang and replacement socket (Dp.f, Ectp.f, Fig. 5D), and is lined labially by a single row of small teeth (Dp.t, Ectp.t, Fig. 5D) similar in shape and size to those of the maxilla. The dermopalatine and ectopterygoid are separated by a fossa for accommodation of the coronoid fangs of the lower jaw. The horizontal lamina of the dermopalatine and ectopterygoid abuts on the palatal lamina of the maxilla.

The large entopterygoid (Entp, Fig 1F, 5D) is fused to the palatoquadrate lingually, obscuring margins between the two. Anteromedially, a sharp ridge above the dermopalatine and ectopterygoid bears several small teeth (Entp.t, Fig. 5D). The lingual face bears minute denticles (Fig. 1D). The dorsal margin of the entopterygoid forms a small, dorsally directed process that projects at the level of the spiraculo-hyomandibular recess.

\section{Mandible}


The mandible comprises the dentary, infradentaries, prearticular, coronoids, Meckelian ossification, and parasymphysial tooth whorl. As with the skull roof, a continuous coat of cosmine obscures divisions between external dermal bones. Many features of the lingual side are covered by matrix and were not described previously (Otto 2007).

The elongate dentary (De, Figs $1 \mathrm{C}, \mathrm{F}, 4 \mathrm{~B}, 5 \mathrm{~B}, \mathrm{~F}, \mathrm{H}, \mathrm{J})$ is almost completely preserved. Only the anteriormost tip is missing, leaving the structure of the attachment for the parasymphysial whorl unclear. The dentary carries a single labial row of small teeth from the anterior limit to the level of the adductor fossa. Large pores pierce the cosmine ventral to the tooth row, likely corresponding to branches of the mandibular canal. In lingual view, the base of the dentary tooth row displays a gutter for contact with the coronoids. A shallow canal, often open as a gutter, extends along the ventral margin of the mandible, and accommodated the mandibular sensory canal (ma.g, Fig. 5F). This canal connects to the lateral face of the mandible by means of numerous narrow pores. The number and extent of the infradentaries cannot be deduced due to the thick cosmine covering. In the anteriormost part of the mandible, a medial expansion between the precoronoid fossa and symphysis corresponds to the splenial flange (vf.Spl, Fig. 5J).

A displaced parasymphysial tooth whorl (pstw, Figs 1F, 5K,L) lies between the palatoquadrate and lower jaw. It has a broad, curved base and bears five symmetrically arranged rows of teeth: a middle row of three large fangs flanked medially and laterally by two rows of smaller teeth. Each of these flanking rows bears five teeth, with individual cusps less than half the size and more rounded in cross sections than those in the central row, and diminishing in size laterally. All teeth are recurved inwards. The ventral surface of the whorl displays a thickened ridge that lies directly underneath the middle tooth row.

There are three coronoids (Co, Fig. 5B, J), decreasing in length from anterior to posterior, with the first coronoid being roughly twice the length of the third. Each coronoid 
bears a fang pair. The first two coronoids display complete fang pairs, comprising a posterior fang laterally overlapping the anterior fang (Co.f, Fig. 5J). Only the anterior fang is present on the posterior coronoid, with a replacement pit for the more posterior one. The vertical lamina of the coronoids is covered by a single row of small teeth (Co.t, Fig. 5J) labial to the fangs. Large intercoronoid fossae mark the boundaries between coronoids (f.in.Co, Fig. 5J) and expose the underlying Meckelian bone. A larger precoronoid fossa (f.p.Co, Fig. 5J), floored by Meckelian bone, separates the first coronoid from the symphysial tip of the dentary.

The prearticular (Prt, Fig. 5D) is completely preserved. It is elongate, with a deep distal portion ventral to the adductor fossa, and a thin and tapering mesial portion lining the coronoids. Its lingual side, except for a smooth articular end, is covered in a shagreen of small denticles. The dorsal margin is sinusoid, with two well-developed semilunar notches at the level of the third coronoid. A dorsal process extends from the rear of coronoid 3 to form the antero-mesial margin of the adductor fossa. The mesial suture of the prearticular with the Meckelian ossification is unclear.

The mesial part of the Meckelian ossification (Mk, Fig. 5D) forms a tapering ridge supporting the prearticular and connecting with the parasymphysial area. The mentomandibular ridge displays a dorsally concave depression, and ventral to it a narrow and antero-posteriorly elongate mentomandibular rib (mnt.ri, Fig 5J). However, the mentomandibular rib is intimately bound to the dentary and cannot be separated in tomograms. The ventral margin of the Meckelian ossification is jagged to accommodate the course of small canals. The distal portion forms the articular region for articulation with the palatoquadrate (ar.Pq, Fig. 57J), which has two large main articulation facets labially and lingually, separated by a small, almond-shaped depression. 


\section{Operculogular series}

The operculogular series is incompletely preserved and somewhat disarticulated. It comprises the opercular, subopercular, branchiostegal rays, submandibular bones and gular. Much of this system was described by Otto (2007) and our treatment of it is brief.

The opercular (Op, Figs 1C, 6) and subopercular (Sop, Figs 1C,F, 6) are split between two blocks, and as such only the anterior portion of each has been CT scanned. The operculum is large, a little under twice the size of the suboperculum. The suboperculum is broadly rectangular, with a pronounced anterodorsal process, and is overlapped by the preoperculum anteriorly (ov.Pop, Fig. 6B).

Ventral to this is a series of rectangular branchiostegal rays (Br, Figs 1C,F, 6). Three branchiostegal rays $(\mathrm{Br} 1-3$, Fig. 6B,D) are preserved in articulation on the left of the specimen, with an additional ray displaced ventrally (Otto 2007: fig. 7A, 8A). A further ray (Br?, Fig. 6B,D), medial to the palate, most likely originates from the right side of the specimen, indicating that four branchiostegals were present on each side.

The left gular (Gu, Figs $1 \mathrm{C}, \mathrm{F}, 6)$ is almost entirely preserved. It is elongate and rectangular, and its lateral margin bears a tuberculated overlap area for the submandibular series (ov.Sbm, Fig. 6B). No pit line is apparent. Anterior to the main gular plate lies a small, bean-shaped accessory median gular (pl.Gm, Fig. 6B). The 'median gular' described by Otto $(2007: 14)$ is a fragment of the main gular plate.

Numerous rectangular submandibulars (Sbm, Figs 1,6) are present. Two are preserved in articulation ventral to the dentary, the most anterior of which tapers anteriorly. Additional submandibulars are displaced between the upper and lower jaws and posterior to the mandible. One submandibular (Sbm, Fig. 1F) appears to be displaced from the right side of 
the specimen. In total, nine submandibulars are preserved, with eight probably on each side of the skull. Lateral line pores and pit lines are entirely absent.

\section{Hyoid arch}

The left hyomandibula and a fragment of the associated symplectic are preserved. Otto's (2007: fig. 2B) "element of the hyoid arch" can be identified as the displaced basioccipital.

The hyomandibula (Hy, Figs 1, 7) is stout and elongate, with a moderately developed opercular process (o.p, Fig. 7D). It has two articular heads, the more dorsal of which (h.d, Fig. 7D) is narrow and elongate, and the more ventral (h.v, Fig. 7D) rounded and posteriorly continuous with a thickened ridge. The ventral margin has a sinusoidal profile, with a concave area underneath the ventral articular head and a convex extension close to the posterior margin. The hyomandibula is pierced dorso-medially by the large hyomandibular canal (di.o.h.c, pr.o.h.c, Fig. 7B,C), from which extend grooves for the nerve mandibularis externus (gr.n.m.e, Fig 7B) dorsally and internus (gr.n.m.i, Fig 7B) ventrally.

The incompletely preserved symplectic (Sym, Fig. 7) was likely cartilaginous distally. It is displaced from life position.

\section{Pectoral girdle}

The pectoral girdle is incompletely preserved and comprises fragments from the cleithrum, clavicle and a putative supracleithrum. Of these elements, most were previously described by Otto (2007). We only briefly describe the cleithrum and scapulocoracoid.

The portion of the right cleithrum $(\mathrm{Cl}$, Figs $1 \mathrm{~F}, 8)$ preserved in the CT-scanned block consists of the ventral blade, which is roughly triangular in shape, broad-based, with a 
tapering anterior projection. The antero-dorsal margin displays a distinct depressed area to accommodate the clavicle (ov.Cla, Fig. 8B). The external surface is covered by a homogenous cosmine sheet. The internal surface displays a dorsal groove for the processus ascendens of the clavicle (g.pr.a.Cla, Fig. 8D), and an elongate ventral area marking the overlap by trunk scales (ov.sc, Fig. 8D).

The scapulocoracoid is attached to the internal surface of the cleithrum (Scc, Fig. 8D). The basal plate is broad, with a narrow anterodorsal expansion, and carries three unevenly developed flanges: a long, shallow anteroventral extension and two short ones ventrally and dorsally. The scapulocoracoid appears to be broken. A mesially directed, somewhat concave surface has the appearance of a glenoid fossa (?gl, Fig. 8D), but its orientation is inconsistent with this interpretation.

\section{DISCUSSION}

The majority of porolepiform taxa are known only from fragmentary or disarticulated examples (e.g., scales, teeth, and jaw fragments). Relatively complete, character-rich material is largely restricted to holoptychiids (e.g., Holoptychius, Glyptolepis, Laccognathus: Ørvig 1957; Jarvik 1972; Vorobyeva 1980, 2006), with 'porolepids' much more poorly known. The articulated material of Durialepis edentatus thus represents an important resource for understanding skeletal evolution in porolepiforms, as well as in dipnomorphs more widely (Fig. 9).

Durialepis shares with Porolepis and Heimenia cosmine-covered dermal bones and rhombic scales, features plesiomorphic for sarcopterygians and osteichthyans (Friedman \& Brazeau 2010; Lu et al. 2016; Mondéjar-Fernández 2018). A mandibular tooth row that terminates anterior to the adductor fossa and two subsidiary squamosals are also common to 
these taxa, although the cheek is poorly known in Heimenia ensis (Clément, 2001b).

Notwithstanding these likely plesiomorphic similarities, the anatomy of Durialepis edentatus deviates from that seen in Porolepis in several ways, reflecting apomorphies and features shared with holoptychiids to the exclusion of other 'porolepids'. Most notable among these are aspects of the operculogular system, dentition, and skull roof.

The operculogular system of Porolepis brevis (Jarvik 1972) and non-porolepiform outgroups such as Guiyu oneiros (Zhu et al. 2009) display three branchiostegal rays on each side of the skull, but Durialepis edentatus and holoptychiids (Jarvik, 1972; Cloutier \& Schultze, 1996) possesses four (Figs 9-10). The gular plates of Porolepis brevis comprise two small accessory gulars (Jarvik 1972), but such structures are absent in holoptychiids; Durialepis edentatus possesses just a single median gular, a condition that can be considered intermediate between Porolepis and holoptychiids. Finally, the concave contact of the preopercular with the quadratojugal is apomorphic for Durialepis edentatus (Fig. 10).

Further variation is seen in the parasymphysial dentition of porolepiforms. A specimen referred to Porolepis sp. (Jarvik 1972; pl. 26:6) displays the putatively primitive condition of eight rows of teeth: five rows of small teeth laterally, two rows of small teeth mesially, and a medial row of large fangs. The tooth whorls of holoptychiids carry five or fewer rows of teeth and larger fangs than those of 'porolepids' (Ahlberg 1992a) but always maintaining the asymmetry. The parasymphysial tooth whorl of Durialepis edentatus, with five rows of teeth in total and large tusks in the median row, is more similar to those of holoptychiids. Furthermore, it is unique amongst porolepiforms in being symmetrical, with the same number of tooth rows on either side of the medial fangs (Fig. 5). Duffichthys mirabilis also departs from the general porolepiform configuration showing a single large fang and two small isolated marginal teeth laterally instead of a series of rows (Ahlberg 1992a). 
Postparietal shields are comparatively poorly known for porolepiforms, and have only been identified for Porolepis brevis, Holoptychius sp. and Glyptolepis groenlandica (Jarvik 1972; Downs et al. 2013), Laccognathus (L. panderi, L. embryi) (Vorobyeva 1980; Downs et al. 2011), Quebecius quebecensis (Cloutier \& Schultze 1996) and Nasogaluakus chorni (Schultze 2000). The relative length of the postparietal shield increases in more nested members of the clade. In Porolepis brevis, the parieto-ethmoidal shield (60\%) is longer than the postparietal shield (40\%). In Glyptolepis groenlandica, Nasogaluakus chorni and Laccognathus (L. panderi, L. embryi), parieto-ethmoidal and postparietal shields are roughly equal in length (45\%/55\% respectively) (Jarvik 1972; Vorobyeva 1980; Schultze 2000; Downs et al. 2011) whereas in other holoptychiids, such as Holoptychius sp., the parietoethmoidal shield (40\%) is much shorter that the postparietal (60\%) (Jarvik 1972). The roughly equal parieto-ethmoidal and postparietal shields (Fig 9B) in Durialepis edentatus resembles holoptychiids like Glyptolepis groenlandica and can be considered intermediate between other 'porolepids' and holoptychiids (Fig. 10).

The shoulder girdle of Durialepis edentatus is remarkable among porolepiforms. The dorsal lamina of the cleithrum appears to be rectangular (Otto 2007), as opposed to the more rounded dorsal margin of other porolepiforms (Clément 2004). The ventral margin of the cleithum displays a groove for the overlapping of the scales, which also occurs in other 'porolepids' (e.g., Porolepis sp., Heimenia ensis) (Jarvik 1972; Clément 2001b) but is absent in holoptychiids (Holoptychius sp, Laccognathus embryi) (Jarvik 1972; Downs et al. 2011). The scapulocoracoid of porolepiforms is virtually unknown, with only the scapulocoracoid scar preserved in Porolepis, Holoptychius and Laccognathus (Andrews \& Westoll 1970; Jarvik 1972; Clément 2001, Downs et al. 2011). The scapulocoracoid of 'porolepids' is thus solely known in Durialepis edentatus, whereas among holoptychiids the only information comes from Glyptolepis sp. (Ahlberg 1989). Both scapulocoracoids have the same general 
features, in displaying a triradiate outline, a transversely elongate glenoid fossa, and lacking perforations for large supraglenoid and supracoracoid foramina. The absence of such foramina in 'porolepids' (Durialepis) as well as in holoptychiids (Glyptolepis) can thus confidently be considered a porolepiform synapomorphy among dipnomorphs, in contrast to Youngolepis praecursor and early lungfishes where such foramina occur (Ahlberg 1989).

The presence of a transverse canal within the endocranium of the snout has not previously been reported in porolepiforms, and, aside from Durialepis edentatus, is otherwise only known in Powichthys spitsbergensis (Clément \& Ahlberg 2010: fig. 7A-B). Connected to this is a complex series of ramifying canals pervading the region, reminiscent of rostral tubuli. Although previously considered to be a synapomorphy of Youngolepis + lungfishes (Cloutier \& Ahlberg 1996), recent tomographic studies of early sarcopterygians have revealed that similar - if less complex — tubule systems are widespread in taxa including onychodonts (Qingmenodus yui: Lu et al. 2016) and tetrapodomorphs (Gogonasus andrewsae: Holland 2014).

Placement of Durialepis edentatus within Porolepiformes is uncontroversial, and this taxon displays the most conspicuous synapomorphies of the clade: multiple subsquamosals, absence of distinct intertemporal and supratemporal bones, and a sensory canal line passing through the postparietal radiation centre (Ahlberg 1991; Cloutier \& Ahlberg 1996; Schultze 2000) (Fig. 9). However, our understanding of internal relationships of porolepiforms has advanced little since Jarvik (1942: 382) first recognized that 'porolepids' and holoptychiids were closely related to one another. Holoptychiids are united by a series of derived features (Ørvig 1957; Cloutier \& Ahlberg 1996), but the interrelationships of the principal genera are unclear (Schultze 2000). By contrast, the Early-Middle Devonian 'porolepids' are only grouped by their absence of derived holoptychiid features and are assumed to represent a grade (Cloutier \& Ahlberg 1996; Clément 2004), although no analysis has tested this 
hypothesis by including multiple 'porolepid' taxa. Within this basic framework, Durialepis edentatus can be recognized as a 'porolepid'-grade taxon, based on the presence of cosmine and rhombic scales.

It is, however, possible to make some broad inferences about the relationships of 'porolepids' relative to each other and to holoptychiids. As implicit in Ørvig's (1969) original description and several subsequent accounts (Jarvik 1972; Clément 2001b; MondéjarFernández \& Clément 2012), 'porolepids' inclusive of Heimenia ensis are unlikely to form a clade. The principal evidence for this has been the intermediate nature of the scales in $H$. ensis, which are rhombic and thus Porolepis-like posteriorly but assume a derived, rounded morphology similar to those of holoptychiids in the anterior half of the body. This intermediate pattern of squamation suggests that Heimenia is more closely related to holoptychiids than Porolepis, although this has never been formally tested.

This historically significant squamation character is joined by variation in mandibular anatomy that is also suggestive of 'porolepid' paraphyly. Ahlberg (1992a) documented important differences in the construction and geometry of the attachment area for the parasymphysial tooth plate in Porolepis and holoptychiids. For instance, in Porolepis, the toothless area of the dentary is a narrow trough aligned with the rest of the dentary teeth, while the toothless area in holoptychiids is convex and expanded to overlie the mentomeckelian ossification (Ahlberg 1992a). Outgroup comparison with Powichthys (P. thorsteinssoni, Jessen 1980; P. spitsbergensis, Clément \& Janvier 2004) suggests that the arrangement in holoptychiids is derived. In this context, it is significant that the mandible referred to Heimenia ensis by Clément (2001a: fig. 6) shows an articular structure for the parasymphysial tooth whorl intermediate in structure between Porolepis and holoptychiids: it is not strongly convex (as in Porolepis sp.), but consists of an extensive posterior lamina that covers the dorsal surface of the mentomandibular (as in holoptychiids) (Jarvik 1972). As with 
the squamation, this feature suggests a sister-group relationship between Heimenia and holoptychiids to the exclusion of Porolepis.

Nevertheless, in the absence of further cranial material for Heimenia ensis or a completely-preserved parasymphysial attachment area for Durialepis edentatus, the relationships of these two 'porolepid' taxa relative to Porolepis and holoptychiids are difficult to determine. Moreover, the monophyly of Porolepis is also unresolved, an enduring problem highlighted since the middle of the $20^{\text {th }}$ century (e.g., Jarvik 1942; Kulczycki 1960; Ørvig 1969). A thorough analysis of porolepiform interrelationships is needed in order to address phylogenetic uncertainties and redress the anatomical imbalance of previous datasets, which were heavily weighted towards the dermal skeleton (Schultze 2000). Such an in-depth new investigation on porolepiform phylogeny will benefit from new endocranial characters now accessible for many porolepiforms such as Glyptolepis (G. paucidens, Henderson et al. in prep) and early dipnomorphs like Powichthys (P. spitsbergenseis, Clément \& Ahlberg 2010). We predict that the inclusion of the new information now available for Heimenia and Durialepis will shed light on the putative paraphyly of 'porolepids', identify the sister taxon of holoptychiids (either Durialepis or Heimenia), and clarify holoptychiid intrarelationships. Reassessment of Porolepis taxonomy in particular, and 'porolepids' in general, will certainly allow early porolepiforms to play a relevant role in future phylogenetic analyses of sarcopterygian interrelationships.

\section{CONCLUSION}

The skull of the Emsian porolepiform Durialepis edentatus from the Eifel Hills of Germany is described here on the basis of high-resolution micro-computed X-ray tomography $(\mu \mathrm{CT})$. This new approach allows the identification of previously concealed 
features, revealing a unique combination of traits for an Early Devonian 'porolepid'. The general arrangement of the cheek and the occurrence of a thick cosmine covering in the scales and dermal bones agree with the primitive porolepiform morphology displayed by Porolepis (e.g., P. brevis). However, the skull roof proportions, the number of branchiostegal rays, the occurrence of a single median gular plate, and the structure of the parasymphysial tooth whorl indicate a more derived position of Durialepis edentatus within early porolepiforms, in particular one more closely related to holoptychiids such as Glyptolepis groenlandica than to Porolepis brevis.

The anatomical data presented for Durialepis edentatus further strengthen the assumption that 'porolepids' represent a grade of primitive porolepiforms and stresses the necessity of a revision of 'porolepid' taxonomy and porolepiform interrelationships. The problem of Porolepis taxonomy is bound up with the broader 'porolepid' problem, and both are beyond the scope of this study. However, we suggest that better characterization of morphology of other 'porolepid' species using $\mu \mathrm{CT}$ might be a useful first step to resolving both issues. This new description of Durialepis edentatus, and the prospect of further anatomical data from its exceptionally preserved braincase, establishes the taxon as a reliable representative of early porolepiforms for further phylogenetic analyses of early dipnomorph — and osteichthyan —interrelationships.

\section{Acknowledgments}

Access to material was facilitated by Michael Amler (Geologisches Institut Köln), Florian Witzmann (MfN, Berlin) and Zerina Johanson (NHM, London). Gaël Clément, Philippe Janvier (MNHN, Paris) and Per Ahlberg (Uppsala University) are warmly thanked for their insightful comments on porolepiform anatomy. The reviews by Jason Downs (Delaware 
Valley University, Philadelphia) and Martin Brazeau (Imperial College, London) improved the paper. JMF was supported by the Société des Amis du Muséum national d'Histoire naturelle and a Synthesis grant. SG was supported by the National Environment Research Council (NE/J500045/1) and a Royal Society Dorothy Hodgkin Research Fellowship.

\section{REFERENCES}

AHLBERG, P. E. 1989. Paired fin skeletons and relationships of the fossil group Porolepiformes (Osteichthyes: Sarcopterygii). Zoological Journal of the Linnean Society, 96, 119-166.

AHLBERG, P. E. 1991. A re-examination of sarcopterygian interrelationships, with special reference to the Porolepiformes. Zoological Journal of the Linnean Society, 103, 241287.

AHLBERG, P. E. 1992a. A new holoptychiid porolepiform fish from the Upper Frasnian of Elgin, Scotland. Palaeontology, 35, 813-828.

AHLBERG, P. E. 1992b. The palaeoecology and evolutionary history of the porolepiform sarcopterygians. Pp. 71-90 in E. Mark-Kurik (ed.), Fossil Fishes as Living Animals. Academy of Sciences of Estonia, Tallinn.

ANDREWS, S. M. and WESTOLL, T. S 1970. The postcranial skeleton of rhipidistian fishes excluding Eusthenopteron. Transactions of the Royal Society of Edinburgh, 68, 391489.

BALL, H. W., DINELEY, D. L. and WHITE, E. I. 1961. The Old Red Sandstone of Brown Clee Hill and the adjacent area. Bulletin of the British Museum (Natural History) (Geology), 5, 175-310.

BERG, L. S. 1937. A classification of fish-like vertebrates. Bulletin de l'Académie des Sciences, de l'URSS, Classe des Sciences mathématiques et naturelles, 4, 1277-1280. 
BLIECK, A. and ELLIOTT, D. K. 2017. Pteraspidomorphs (Vertebrata), the Old Red Sandstone, and the special case of the Brecon Beacons National Park, Wales, UK. Proceedings of the Geologists' Association, 128(3), 438-446.

CLÉMENT, G. 2001a. Evidence for lack of choanae in the Porolepiformes. Journal of Vertebrate Paleontology, 21, 795-802.

CLÉMENT, G. 2001b. Etudes anatomiques des genres Porolepis, Woodward 1891 et Heimenia Ørvig, 1969 ("Porolepididae”, Sarcopterygii) et du genre Powichthys Jessen, 1975 (Powichthyidae, Sarcopterygii) du Dévonien Inférieur et Moyen du SpitzbergPhylogénie des Dipnomorpha. Ph.D. dissertation, Muséum National d'Histoire Naturelle de Paris, Paris. 297 pp.

CLÉMENT, G. 2004. Nouvelles données anatomiques et morphologie générale des "Porolepididae" (Dipnomorpha, Sarcopterygii). Revue de Paléobiologie, Genève. Vol. spéc. 9, 193-211.

CLÉMENT, G. and JANVIER, P. 2004. Powichthys spitsbergensis sp. nov., a new member of the Dipnomorpha (Sarcopterygii, lobe-finned fishes) from the Lower Devonian of Spitsbergen, with remarks on basal dipnomorph anatomy. Fossils and Strata, 50, 92112.

CLÉMENT, G. and AHLBERG, P. E. 2010. The endocranial anatomy of the early sarcopterygian Powichthys from Spitsbergen, based on CTscanning. Pp. 363-377 in D. K. Elliot, J. G. Maisey, X. Yu, and D. Miao (eds.), Morphology, Phylogeny and Paleobiogeography of Fossil Fishes. Verlag Dr. Friedrich Pfeil, Munich.

CLOUTIER, R. and AHLBERG, P. E. 1996. Morphology, characters, and the interrelationships of the basal Sarcopterygians. Pp. 445-479 in M. L. J. Stiassny, L. R. Parenti, and G. D. Johnson (eds.), Interrelationships of Fishes II. Academic Press, New York.

CLOUTIER, R. and SCHULTZE, H.-P. 1996. Porolepiform fishes (Sarcopterygii). Pp. 248270 in H.-P. Schultze and R. Cloutier (eds.), Devonian Fishes and Plants of Miguasha, Québec, Canada. Verlag Dr. Friedrich Pfeil, Munich. 
DOWNS, J. P., DAESCHLER, E. B., JENKINS, F. A. JR. and SHUBIN, N. H. 2011. A new species of Laccognathus (Sarcopterygii, Porolepiformes) from the Late Devonian of Ellesmere Island, Nunavut, Canada. Journal of Vertebrate Paleontology, 31, 981-996.

DOWNS, J. P., DAESCHLER, E. B., JENKINS, F. A. JR. and SHUBIN, N. H. 2013. Holoptychius bergmanni sp. nov. (Sarcopterygii, Porolepiformes) from the Upper Devonian of Nunavut, Canada, and a review of Holoptychius taxonomy. Proceedings of the Academy of Natural Sciences of Philadelphia, 162, 47-59.

FRIEDMAN, M. and BRAZEAU, M. D. 2010. A reappraisal of the origin and basal radiation of the Osteichthyes. Journal of Vertebrate Paleontology, 30, 36-56.

GROSS, W. 1933. Die unterdevonischen Fische und Gigantostraken von Overath. Abhandlungen der Preusischen Geologischen Landesanstalt, 145, 41-77.

GROSS, W. 1936. Beiträge zur Osteologie baltischer und rheinischer DevonCrossopterygier. Paläontologische Zeitschrift, 18, 129-155.

GROSS, W. 1941. Uber den Unterkiefer einiger devonischer Crossopterygier. Abhandlungen der Preussischen Akademie der Wissenschaften. Math. Naturw. Klasse, 7, 1-51.

GROSS, W. 1956. Über Crossopterygier und Dipnoer aus dem baltischen Oberdevon im Zusammenhang einer vergleichenden Untersuchung des Porenkanalsystems paläozoischer Agnathen und Fische. Kungliga Svenska Vetenskapsakademiens Handlingar, 5(6), 1-140.

HOLLAND, T. 2014. The endocranial anatomy of Gogonasus andrewsae Long, 1985 revealed through micro CT-scanning. Earth and Environmental Science Transactions of the Royal Society of Edinburgh, 105(1), 9-34.

HUXLEY, T. H. 1880. On the application of the Laws of Evolution to the arrangement of the Vertebrata, and more particularly of the Mammalia. Proceedings of the Zoological Society of London, 43, 649-662.

JANSEN, U. 2016. Brachiopod faunas, facies and biostratigraphy of the Pridolian to lower Eifelian succession in the Rhenish Massif (Rheinisches Schiefergebirge, Germany). Geological Society, London, Special Publications, 423(1), 45-122.

JANVIER, P. 1996. Early Vertebrates. Oxford University Press, U.K., 393pp. 
JARVIK, E. 1942. On the structure of the snout of crossopterygians and lower gnathostomes in general. Zoologiska Bidrag fran Uppsala, 21, 235-675.

JARVIK, E. 1972. Middle and Upper Devonian Porolepiformes from East Greenland with special reference to Glyptolepis groenlandica n. sp., and a discussion on the structure of the head in the Porolepiformes. Meddelelser om Grønland, 187(2), 1-307.

JARVIK, E. 1980. Basic Structure and Evolution of Vertebrates, Volume 1. Academic Press, London, $575 \mathrm{pp}$.

JESSEN, H. L. 1980. Lower Devonian Porolepiformes from the Canadian Arctic with special reference to Powichthys thorsteinssoni Jessen. Palaeontographica Abteilung A, 167, $180-214$.

JESSEN, H. L. 1989. Ein rhipidistier Fischrest aus den Klerf-Schichten (oberes UnterDevon) der Eifel (Rheinisches Schiefergebirge). Palaeontographica, Abteilung A, 206, $17-24$.

JOHANSON, Z., AHLBERG, P. E. and RITCHIE, A. 2013. First record of Porolepis (Sarcopterygii; Porolepiformes) from eastern Gondwana. Canadian Journal of Earth Sciences, 50(3), 249-253.

KADE, G. 1858. Ueber die Devonischen Fishreste eines Diluvialblockes. Programm der Königlichen Realschule zu Meseritz. 24 pp.

KULCZYCKI, J. 1960. Porolepis (Crossopterygii) from the Lower Devonian of the Holy Cross Mountains. Acta Palaeontologica Polonica, 5, 65-104.

LEBEDEV, O. and LUKSEVICS, E. 2018. New materials on Ventalepis ketleriensis Schultze, 1980 extend the zoogeographic area of a Late Devonian vertebrate assemblage. Acta Geologica Polonica, 68(3), 437-454.

LU, J., GILES, S., FRIEDMAN, M., DEN BLAAUWEN, J. L. and ZHU, M. 2016. The oldest actinopterygian highlights the cryptic early history of the hyperdiverse rayfinned fishes. Current Biology, 26(12), 1602-1608.

MAISEY, J. G. 1986. Heads and tails: a chordate phylogeny. Cladistics, 2(3), 201-256. 
MILLER, R. F. and BRAZEAU, M. D. 2007. A Late Devonian Porolepiform fish (Holoptychius) and the age of the Kennebecasis Formation, southern New Brunswick, Canada. Atlantic Geology, 43, 187-196.

MONDÉJAR-FERNÁNDEZ, J. 2018. On cosmine: its origins, biology and implications for sarcopterygian interrelationships. Cybium, 42(1), 41-65.

MONDÉJAR-FERNÁNDEZ J. and CLÉMENT, G. 2012. Squamation and scale microstructure evolution in the Porolepiformes (Sarcopterygii, Dipnomorpha) based on Heimenia ensis from the Devonian of Spitsbergen. Journal of Vertebrate Paleontology, 32, 267-284.

MONDÉJAR-FERNÁNDEZ, J. and JANVIER, P. 2014. Further evidence for the presence of holoptychiid porolepiforms (Sarcopterygii, Dipnomorpha) from the Frasnian of Colombia. Comptes Rendus Palévol, 13(7), 587 -597.

OBRUCHEV, D. V. 1933. Description of four new species from the Devonian of Leningrad Province. Material of the Central Scientfic Geological and Prsospecting Institute. Palaeontology and Stratigraphy Magazine, 1, 12-14.

ØRVIG, T. 1957. Remarks on the vertebrate fauna of the Lower Upper Devonian of Escuminac Bay, P. Q., Canada, with special reference to the Porolepiform Crossopterygians. Arkiv för Zoologi, 2(10), 481-490.

ØRVIG, T. 1969. Vertebrates from the Wood Bay Group and the position of the EmsianEifelian boundary in the Devonian of Vestspitsbergen. Lethaia, 2, 273-328.

OTTO, M. 2007. Durialepis edentatus n. gen., n. sp., ein neuer Rhipidistier (Osteichthyes, Sarcopterygii) aus dem Unter-Devon des Rheinischen Schiefergebirges. Geologica et Palaeontologica, 41, 3-25.

PANCHEN, A. L. and SMITHSON, T. R. 1987. Character diagnosis, fossils and the origin of tetrapods. Biological Reviews, 62, 341-438.

ROMER, A. S. 1955. Herpetichthyes, Amphibioidei, Choanichthyes, or Sarcopterygii? Nature, 176, 126. 
SCHULTZE, H.-P. 1969. Die Faltenzähne der Rhipidistiiden Crossopterygier, der Tetrapoden und der Actinopterygier-gattung Lepisosteus. Palaeontographica Italica, 65, 63-136.

SCHULTZE, H.-P. 1980. Crossopterygier-Schuppen aus dem obersten Oberdevon Lettlands (Osteichthyes, Pisces). Neues Jahrbuch für Geologie und Paläontologie, Monatshefte, 4, 215-228.

SCHULTZE, H.-P. 2000. A porolepiform rhipidistian from the Lower Devonian of the Canadian Arctic. Fossil Record, 3, 99-109.

SCHULTZE, H.-P. and ARSENAULT, M. 1987. Quebecius quebecensis (Whiteaves), a porolepiform crossopterygian (Pisces) from the Late Devonian of Québec, Canada. Canadian Journal of earth Sciences, 24, 2351-2361.

THOMSON, K. S. 1966. Glyptolepis from the Middle Devonian of Scotland. Postilia, 99, $1-$ 10.

VOROBYEVA, E. I. 1980. Observations on two rhipidistian fishes from the Upper Devonian of Lode, Latvia. Zoological Journal of the Linnean Society, 70, 191-20.

VOROBYEVA, E. I. 1987. Porolepid crossopterygian from the Middle Devonian of Estonia. Paleontologicheskii Zhurnal, 1987(1), 76-85 [In Russian].

VOROBYEVA, E. I. 2006. A new species of Laccognathus (Porolepiform Crossopterygii) from the Devonian of Latvia. Paleontological Journal, 40(3), 312-322.

ZHU, M., ZHAO, W., JIA, L., LU, J., QIAO, T. and QU, Q. 2009. The oldest articulated osteichthyan reveals mosaic gnathostome characters. Nature, 458, 469-474. 


\section{FIGURES}

Figure 1. Cranium of Durialepis edentatus Otto 2007. Photograph (A), render (B) and interpretative drawing (C) in left lateral view. Photograph (D), render (E) and interpretative drawing $(F)$ in medial view. Decoloured portion of the fossil specimen not scanned. Scale bar equals $10 \mathrm{~mm}$.

Abbreviations: a.no, anterior nostril; Br, branchiostegal rays; Cl, cleithrum; De, dentary; Eth, ethmoid division of the skull; Ext, extratemporal; Gu, gular; Hy, hyomandibula; L.Ex, lateral extrascapular; Op, opercular; Otoc, otoccipital division of the skull; p.no, posterior nostril; PaE, parieto-ethmoidal shield; pl.L.Ex, pit line of lateral extrascapular; pl.Pa, pit line of parietal; Pp, postparietal; Prsp, prespiracular; pstw, parasymphysial tooth whorl; Sbm, submandibular; Sop, subopercular; Vo, vomer.

Figure 2. Skull roof of Durialepis edentatus Otto 2007. Render (A) and interpretative drawing (B) of ethmoid division in dorsal view. Render (C) and interpretative drawing (D) of otoccipital division in dorsal view. Render (E) and semi-transparent render (F) of lateral skull bones (prespiracular and extratemporal and lateral extrascapular) in dorsal view. Scale bar equals $10 \mathrm{~mm}$.

Abbreviations: Ext, extratemporal; gc.Ext, growth centre of extratemporal; gc.L.Ex, growth centre of lateral extrascapular; L.Ex, lateral extrascapular; occp, occiput; ov.m.Ext, overlapping facet for median extrascapular; ov.Po, overlapping facet for the postorbital; ov.Prsp, overlapping facet for prespiracular; pi.fo, pineal foramen; pl.Pa, pit line of parietal; pl.Pp, pit line of postparietal; pl.Ta, pit line of tabular; poc, postotic lateral line canal; poc.Ext, extratemporal ramification of the postotic lateral line canal; Pp, postparietal; Prsp, 
prespiracular; soc, supraorbital lateral line canal; scc, supratemporal commissure; su.Pa, parietal suture; su.Pp, postparietal suture; Ta, tabular.

Figure 3. Lateral line system and sensory canal network of Durialepis edentatus Otto 2007. Renders of parieto-ethmoidal shield in dorsal view, with dermal bone removed (A, B) and rendered semi-transparent $(\mathrm{C})$. Renders of postparietal shield in dorsal view, with dermal bone removed (D, E) and rendered semi-transparent (F). Scale bar equals $10 \mathrm{~mm}$.

Abbreviations: Eth.co, ethmoid commissure; ex.poc.Ta, tabular expansion of supraorbital lateral line canal; gc.Pa, growth centre of parietal; gc.Pp, growth centre of postparietal; gc.Ta, growth centre of tabular; ioc, infraorbital lateral line canal; opn, opening of the main trunk of sensory canal network; Pa, parietal; poc, postotic lateral line canal; Pp, postparietal; soc, supraorbital lateral line canal; Ta, tabular; tr.c, transverse canal.

Figure 4. Cheek and vomer of Durialepis edentatus Otto 2007. Render (A) and interpretative drawing (B) of cheek in left lateral view. Scale bar equals $10 \mathrm{~mm}$. Render (C) and interpretative drawing (D) of left vomer in ventral view. Scale bar equals $5 \mathrm{~mm}$ Abbreviations: De, dentary; h.Vo, horizontal lamina of vomer; Ju, jugal; La, lacrimal; Mx, maxilla; ?pl.Qj, pit line of quadratojugal; Po, postorbital; Pop, preopercular; Prsp, prespiracular; Psbm, preoperculosubmandibular; pstw, parasymphysial tooth whorl; Qj, quadratojugal; Sq, principal squamosal; sSq, subsidiary squamosal; v.Vo, vertical lamina of vomer; Vo.f, vomeral fang; Vo.t, vomeral tooth.

Figure 5. Jaws and palate of Durialepis edentatus Otto 2007. Render (A) and interpretative drawing (B) of left inner dental series in labial view. Render (C) and interpretative drawing (D) of left inner dental series in lingual view. Render (E) and interpretative drawing (F) of 
left dermal jaw bones in labial view. Render $(\mathrm{G})$ and interpretative drawing $(\mathrm{H})$ of left dermal jaw bones in lingual view. Render (I) and interpretative drawing $(\mathrm{J})$ of left lower jaw in dorsal view. Render of parasymphysial tooth whorl in right labial (K) ad anterior (L) view. Scale bar equals $10 \mathrm{~mm}$.

Abbreviations: ad.f, adductor fossa; ar.Pq, articulation for palatoquadrate; ar.pstw, articulation area of parasymphysial dental plate; Co, coronoid; Co.f, coronoid fang; Co.t, coronoid teeth; d.m.Pq, dorsal margin of palatoquadrate; De, dentary; De.t, dentary teeth; d.m, dorsal margin of palatoquadrate; Dp, dermopalatine; Dp.f, dermopalatine fang; Dp.t, dermopalatine teeth; Ectp, ectopterygoid; Ectp.f, ectopterygoid fang; Ectp.t, ectopterygoid teeth; Entp, entopterygoid; Entp.t, entopterygoid teeth; f.in.Co, intercoronoid fossa; f.p.Co, precoronoid fossa; fo.ad; adductor fossa; ma.g, groove for the passage of the mandibular canal; Mk, meckelian ossification; mnt.ri, mentomandibular rib; Mx, maxilla; ov.Qj, overlapping facet for quadratojugal; pa.au, pars autopalatina of palatoquadrate; pa.qd, pars quadrata of palatoquadrate; Pq, palatoquadrate; pr.as, processus ascendens of palatoquadrate; Prt, prearticular; re.sh, spiraculo-hyomandibular recess; sbm.g, submandibular groove; Spl, splenial; vf.Spl, ventral flange of splenial.

Figure 6. Operculogular series of Durialepis edentatus Otto 2007. Render (A) and interpretative drawing (B) in left lateral view. Render (C) and interpretative drawing (D) in medial view. Scale bar equals $10 \mathrm{~mm}$.

Abbreviations: Br, branchiostegal ray; Gu, gular; Op, opercular; ov.Psbm, overlapping facet for preoperculosubmandibular; ov.Sbm, overlapping facet for submandibulars; pl.Gm, median gular plate Sbm, submandibular; Sop, subopercular. 
Figure 7. Hyoid arch of Durialepis edentatus Otto 2007. Render (A) and interpretative drawing (B) in left lateral view. Render (C) and interpretative drawing (D) in medial view. Scale bar equals $10 \mathrm{~mm}$.

Abbreviations: di.o.h.c, distal opening of hyomandibular canal; h.d, dorsal articulation facet of hyomandibula; h.v, ventral articulation facet of hyomandibula; gr.n.m.e, groove for the mandibularis externus nerve; gr.n.m.i, groove for the mandibularis internus nerve; Hy, hyomandibula; pr.o.h.c, proximal opening of hyomandibular canal; o.p, opercular process; Sym, symplectic.

Figure 8. Shoulder girdle of Durialepis edentatus Otto 2007. Render (A) and interpretative drawing (B) in right lateral view. Render (C) and interpretative drawing (D) in medial view. Scale bar equals $10 \mathrm{~mm}$.

Abbreviations: Cl, cleithrum; g.pr.a.Cla, groove for the articulation of the anterior process of clavicle; ?gl, incompletely preserved glenoid fossa; ov.Cla, overlapping facet for clavicle; ov.sc, ridge for the overlapping of trunk scales; Scc, scapulocoracoid.

Figure 9. Reconstruction of the skull of Durialepis edentatus Otto 2007 in lateral (A) and dorsal (B) view. Grey lines indicate the course of the lateral line system. Scale bar equals 10 $\mathrm{mm}$.

Abbreviations: a.no, anterior nostril; Br, branchiostegal rays; De, dentary; Eth.co, ethmoid commissure; Ext, extratemporal; Gu, gular; ioc, infraorbital lateral line canal; Ju, jugal; La, lacrimal; L.Ex, lateral extrascapular; M.Ex, median extrascapular; Mx, maxilla; Op, opercular; orb, orbit; ov.Po, overlapping facet for postorbital; ov.Prsp, overlapping facet for prespiracular; p.no, posterior nostril; PaE, parietoethmoidal shield; pi.fo, pineal foramen; pl.L.Ex, pit line of lateral extrascapular; pl.Pa, pit line of parietal; pl.Pp, pit line of 
postparietal; pl.Ta, pit line of tabular; Po, postorbital; poc, postotic lateral line canal; poc.Ext, extratemporal ramification of the postotic lateral line canal; Pp, postparietal; Pop, preopercular; Prsp, prespiracular; Psbm, preoperculosubmandibular; Qj, quadratojugal; Sbm, submandibular; scc, supratemporal commissure; soc, supraorbital lateral line canal; Sop, subopercular; Sq, squamosal; sSq, subsidiary squamosal; su.Pa, parietal suture; su.Pp, postparietal suture; Ta, tabular.

Figure 10. Comparison of dermal skull patterns across porolepiforms in lateral (A, C, E, G, I, scale bar equals $10 \mathrm{~mm}$ ) and dorsal (B, D, F, H, J not to scale) views. Porolepis brevis (A-B) after Jarvik 1972. Nasogaluakus chorni (C-D) after Schultze 2000. Laccognathus panderi (EF) after Vorobyeva 1980. Glyptolepis groenlandica (G-H) after Jarvik 1972. Holoptychius sp. (I-J) after Jarvik 1972.

Abbreviations: Br, branchiostegal rays; De, dentary; Ext, extratemporal; Gu, gular; Ifd, infradentary series; Ju, jugal; La, lacrimal; L.Ex, lateral extrascapular; M.Ex, median extrascapular; Mx, maxilla; Op, opercular; Pa, parietal; PaE, parieto-ethmoidal shield; Po, postorbital; Pp, postparietal; Pop, preopercular; Prsp, prespiracular; Psbm, preoperculosubmandibular; Qj, quadratojugal; Sbm, submandibular series; Sop, subopercular; Sq, squamosal; sSq, subsidiary squamosal; Ta, tabular. 